\title{
ANALISIS KEMAMPUAN GURU AKIDAH AKHLAK DALAM PENYUSUNAN RENCANA PELAKSANAAN PEMBELAJARAN (RPP) KURIKULUM 2013 DI MTS NEGERI KOTA PALOPO
}

\author{
Arifuddin ${ }^{1)}$ \\ 1, Institut Agama Islam Negeri Palopo, Indonesia \\ email:arifuddin_arif@iainpalopo.ac.id \\ Muthia Muthmainnah ${ }^{3)}$ \\ 3, Pendidikan Agama Islam, Institut Agama Islam Negeri Palopo \\ Email: muthiamuthmainnah98@gmail.com
}

\begin{abstract}
The purpose of this study was to analyze the ability of teachers of the Islamic Morals in preparing the 2013 Curriculum Lesson Plan (RPP) in MTs Negeri Kota Palopo by using descriptive qualitative research methods. The qualitative descriptive method is a method used in research to analyze a problem that occurs and describe it based on data obtained from the results of research in the form of written or oral words of the problem being studied / traced. The author was conducted the research data collection by using 3 (three) instruments, namely observation, interviews, and documentation. The results showed that the ability of teachers of the Islamic Morals in preparing the 2013 Curriculum Lesson Plan (RPP) in the MTs Negeri Kota Palopo was categorized as "good" with 3 (three) stages of observation by the writer. The results of the first observation score were $86 \%$, the second was $78 \%$, and the third was $86 \%$ with an average score of $83.33 \%$ achievement ability, this is evident from the completeness of the Lesson Plan (RPP) made by the teacher concerned. However the ability achieved is not necessarily obtained directly without being influenced by several factors. This achievement was based on 2 (two) factors which consist of internal factors and external factors.
\end{abstract}

Keywords: Drafting Lesson Plan; 2013 Curriculum.

\begin{abstract}
Abstrak: Tujuan dari penelitian ini adalah untuk menganalisis kemampuan guru Akidah Akhlak dalam menyusun Rencana Pelaksanaan Pembelajaran (RPP) Kurikulum 2013 di MTs Negeri Kota Palopo dengan menggunakan metode penelitian deskriptif kualitatif. Metode deskriptif kualitatif yakni cara yang dipakai dalam penelitian untuk menganalisis suatu permasalahan yang terjadi serta mendeskripsikannya berdasarkan data yang didapatkan dari hasil penelitian berupa kata-kata tertulis ataupun lisan dari masalah yang sedang dikaji/ditelusuri. Penulis mengadakan pengumpulan data penelitian dengan menggunakan 3 (tiga) instrumen yaitu observasi, wawancara, dan dokumentasi. Hasil penelitian memperlihatkan bahwa kemampuan guru Akidah Akhlak dalam penyusunan Rencana Pelaksanaan Pembelajaran (RPP) kurikulum 2013 di MTs Negeri Kota Palopo dikategorikan "baik" dengan 3 (tiga) tahapan observasi oleh penulis. Hasil skor observasi pertama yaitu $86 \%$, kedua yaitu $78 \%$, dan ketiga yaitu $86 \%$ dengan rata-rata skor $83,33 \%$ ketercapaian kemampuan, ini terlihat dari kelengkapan Rencana Pelaksanaan Pembelajaran (RPP) yang dibuat oleh guru yang bersangkutan. Namun kemampuan yang diraih tersebut tidak serta merta didapatkan begitu saja tanpa dipengaruhi oleh beberapa faktor. Pencapaian tersebut didasari oleh 2 (dua) faktor yang terdiri dari faktor internal dan faktor eksternal.
\end{abstract}

Kata Kunci: Kurikulum 2013; Penyusunan RPP.

\section{Pendahuluan}

UU Sistem Pendidikan Nasional No. 20 tahun 2003 ayat 1 menguraikan bahwa Standar Nasional Pendidikan mencakup beberapa standar yaitu standar kompetensi lulusan, standar isi, standar proses, standar kompetensi lulusan, standar tenaga pendidik dan kependidikan, standar sarana dan prasarana, standar pengelolaan, standar pembiayaan, dan standar penilaian pendidikan. Lebih rinci disebutkan dalam Peraturan Pemerintah (PP) Nomor 19 tahun 2005 tentang Standar Nasional Pendidikan, bahwa standar proses sebagai salah satu standar yang perlu dikembangkan.
Menjadi patokan dasar penilaian minimum dalam menjalankan proses kegiatan pembelajaran untuk tiap satuan pendidikan di Indonesia yangdiberlakukan pada semua jenjang pendidikan dasar dan menengah jalur pendidikan formal yang menerapkan sistem paket maupun itu sistem kredit semester. ${ }^{1}$

Untuk meningkatkan mutu pendidikan, maka proses pembelajaran atau pendidikan perlu memperhatikan pemenuhan standar di atas. Namun da-

${ }^{1}$ Badan Standar Nasional Pendidikan, Peraturan Menteri Pendidikan RI No. 41 Tahun 2007 Tentang Standar Proses Untuk Satuan Pendidikan Dasar dan Menengah, (Jakarta, Bumi Aksara, 2007), h. 5 
lam penelitian ini penulis fokus kepada salah satu standar yaitu standar

tenaga pendidik (guru). Salah satu unsur yang ikut berperan penting dalam proses pembelajaran, sebagai pengendali siswa agar berhasil dalam kegiatan belajar. Guru yang dimaksud adalah guru profesional. Guru yang mumpuni apabila ia mengerjakan tugas pokoknya sebagai seorang pendidik dan pengajar. Memiliki kemampuan dalammerencanakan, menjalankan, dan mengevaluasi hasil pembelajaran secara baik. ${ }^{2}$ Pembelajaran yang efektif dan efisien dapat dijalankan oleh guru yang unggul dalam kompetensi kepribadian, kompetensi pedagogik, kompetensi profesional, dan kompetensi sosialnya.

Degeng dalam B. Uno menjelaskan bahwa pembelajaran atau pengajaran ialah ikhtiar dalam membelajarkan siswa. ${ }^{3}$ Pendapat tersebut secara tersirat menjelaskan bahwa dalam pembelajaran terdapat beberapa kegiatan perencanaan. Mulai kegiatan memilih, memutuskan, dan mengembangkan metode untuk mencapai hasil pembelajaran yang diharapkan. Kegiatan perencanaan pembelajaran urgen memperhatikan aspek kebutuhan dan kondisi siswa sebagai inti perencanaan pembelajaran.

Perencanaanpembelajaran merupakan salah satu hal urgen dipersiapkan dengan matang sebelum proses pembelajaran dimula. Perencananan bertujuan, agar penyampaian materi pelajaran sistematis, interaktif, inspiratif, menyenangkan, menantang, memotivasi peserta didik untuk berpartisipasi aktif, dan tujuan pembelajaran dapat tercapai.

Perencanaan pembelajaran, sering dihubungkan dengan istilah perangkat pembelajaran atau penyusunan RPP, merupakan tugas administrasi

\footnotetext{
${ }^{2}$ Victor Uji Kurnia, "Definisi Guru Profesional”, Blog Victor Uji Kurnia. http://informasipendidikan.com/2013/07/definisi -guru -profesional.html (22 Desember 2019)

${ }^{3}$ Hamzah B. Uno, Orientasi Baru dalam Psikologi Pembelajaran, (Jakarta: Bumi Aksara, 2006), h. 1
}

guru yang urgen disiapkan sebelum proses pembelajaran dilaksanakan. Perangkat pembelajaran menjadi pedoman guru yang berdampakkepada kepentingan pembelajaran. Menurut Suharsimi bahwa penyusunan RPP, urgen diperhatikan sebelum melaksanakan proses pembelajaran. Bertujuan untukmengetahui kecakapan guru dalam mengolah semua kegiatan pembelajaran yang termuat di dalam RPP. ${ }^{4}$

Penelitian Lailatul Bariyah, Analisis kesesuaian RPP dan pelaksanaan pembelajaran guru SMPN di kabupaten Mojokerto pada sub materi fotosintesis dengan kurikulum 2013 menunjukkan bahwa kelengkapan RPP buatan guru pada sub materi fotosintesis dikelompokkan sesuai dengan kurikulum 2013 sebesar 89,6\%.5 Erni Vidiarti, Zulhaini, dan Andrizal dalam penelitiannya juga menemukan bahwa kemampuan guru PAI dalam penyusunan RPP kurikulum 2013 di SDN 016 Sumber Datar Singingi sudah menunjukkan hasil yang sangat baik dengan rata-rata skor 86,25\%.6 Berdasarkan penelitian tersebut, maka penelitian ini fokus untuk menganalisis kemampuan guru Akidah Akhlak dalam menyusun rencana pelaksanaan pembelajaran (RPP) kurikulum 2013 di MTs Negeri Kota Palopo.

\section{Metode Penelitian}

Penelitian ini merupakan penelitian defkriptif dengan menggunakan pendekatan kualitatif.Penelitian bertujuan untuk memahami fenomena yang terjadi pada objek penelitian yang

${ }^{4}$ Suharsimi Ari Kunto, Prosedur Penelitian: SuatuPendekatan Praktek, (Jakarta: Rineka Cipta, 2010), h. 57

${ }^{5}$ Lailatul Bariyah, Analisis Kesesuaian RPP dan Pelaksanaan Pembelajaran Guru SMPN di Kabupaten Mojokerto pada Sub Materi Fotosintesis dengan Kurikulum 2013. Jurnal BioEdu (Berkah Ilmiah Pendidikan Biologi, Vol. 3, Vo. 3, 2014. h. 453460.

https://jurnalmahasiswa.unesa.ac.id/index.php/bioedu/article/do wnload/ 9558/9439.

${ }^{6}$ Erni Vidiarti, dkk. Analisis Kemampuan Guru Pendidikan Agama Islam dalam Penyusunan Rencana Pelaksanaan Pembelajaran (RPP) Kurikulum 2013, Jurna Pendidikan Agama Islam Vol. 5, No. 2, 2019. h. 102-112. http://ejournal.uinmalang.ac.id/index.php/jpai/ 
diteliti berdasarkan data kualitatif yang terkumpul.

Data yang telah terkumpul dideskripsikan dalam bentuk tertulis dengan menggunakan metode ilmiah.

Objek penelitian ini adalah guru Akidah Akhlak di MTs Negeri Kota Palopo dalam menyusun RPP K13. Data penelitian diperoleh melalui kegiatan observasi, wawancara, dan dokumentasi guru Akidah Akhlak di MTs Negeri Kota Palopo. Guruguru tersebut yakni ibu Herlina, S.Pd.I di kelas VII a, ibu Nasirah, S.Pd.I., M.Pd.I. di kelas VIII e, dan ibu Sitti Hajrah, S.Ag. di kelas IX b.

\section{Hasil Dan Pembahasan}

\section{Definisi Rencana Pelaksanaan Pembelajaran (RPP)}

Menurut Permendikbud No. 22 tahun 2016 mengenai Standar Proses Pendidikan Dasar dan Menengah menjelaskan bahwa Rencana Pelaksanaan Pembelajaran (RPP) merupakan suatu kegiatan pembelajaran yang direncanakan untuk satu kali pertemuan ataulebih. RPP dikembangkan berdasarkan silabus yang ada untuk menunjukkan usaha kegiatan pembelajaran peserta didik dalam mencapai kompensi dasar. ${ }^{7}$

Sedangkan menurut Mulyasa, RPP ialah suatu kegiatan menetapkan keputusan tentang pembelajaran danlangkah yang akan dilaksanakan kedepannya, strategi dalam mencapai tujuan yang dikehendaki, melaksanaan kegiatan secara sistematis dan kontinu. ${ }^{8}$ Dengan demikian, RPP merupakan suatu konsep pembelajaran pada tiap mata pelajaran yang akan dipraktikkan guru di setiap kelasnya.

RPP berfungsi sebagai rujukan guru dalam kegiatan pembelajaran, agar proses pembelajaran

\footnotetext{
${ }^{7}$ Mulyasa, Kurikulum Tingkat Satuan Pendidikan, (Bandung: PT. Remaja Rosdakarya, 2007), h. 212

${ }^{8}$ Mulyasa, Kurikulum Tingkat Satuan Pendidikan, (Bandung: PT. Remaja Rosdakarya, 2007), h. 222
}

tercapai secara maksimal. ${ }^{9}$ Sehingga dalam membuat RPP perlu perencanaan yang matang untuk mencapai kualitas yang baik. Berupaya menghubungkan antarkomponen pembelajaran. Komponen yang dimaksud yakni Kompetensi Inti (KI), Kompetensi Dasar (KD), indikator pencapaian kompetensi, materi, dan penilaian.

Setiap guru pada satuan pendidikan, urgen membuat RPP secara komplit dan terstruktur agar pembelajaran berjalan secara efektif, efisien, interaktif, inspiratif, membahagiakan, menggugah tekad untuk meningkatkan kemampuan, dorong untuk melakukan sesuatu, serta memiliki ruang dalam berkreativitas berdasarkan minat, bakat, psikologis, serta perkembangan siswa. ${ }^{10}$ RPP dalam proses pembelajaran sebagai alat panduan guru yang cukup penting, menjadi rujukan dan solusi atas kesulitan dan tidak sistematisan materi pembelajaran.

\section{Fungsi Rencana Pelaksanaan Pembelajaran (RPP)}

Mulyasa mengungkapkan beberapa fungsi utama dalam perencanaan pembelajaran seperti berikut ini: 11

1. Menetapkan standar kemampuan (kompetensi) yang hendak dicapai pada kegiatan pembelajaran yang akan dilaksanakan. Penetapan standar kemampuan tersebut merupakan hal urgen dalam kesuksesan proses perencanaan. Sebaliknya penetapan kompetensi yang keliru akan berakibat fatal pada:

a. Kompetensi tidak tercapai.

b. Ketidaksesuaian antara kebutuhan dengan harapan pemangku kepentingan.

9Muslich, Kurikulum Tingkat Satuan Pendidikan: Dasar Pemahaman dan Pengembangan, (Jakarta: Bumi Aksara, 2008), h. 45

${ }^{10}$ Yuliharti, dkk, Modul Pengembangan Rencana Pelaksanaan Pembelajaran, (Pekanbaru: Zanafa Publishing, 2014), h. 14

${ }^{11}$ Mulyasa, Kurikulum Tingkat Satuan Pendidikan, (Bandung: PT. Remaja Rosdakarya, 2007), h. 218 
c. Kesalahan memilih prioritas berakibat pada terjadinya pemakaian sumber daya yang berlebihan dan tidak dapat dikembangkan secara kontinu.

2. Mengambil standar kemampuan (kompetensi) yang terlalu tinggi, akan berakibat pada sulitnya dalam penerapan pembelajaran.Standar kemampuan dibuat selaras dengan tingkat perkembangan siswa, membedakan antara peserta didik yang memiliki kemampuan dibawah rata-rata dan peserta didik dengan tingkat kemampuan diatas rata-rata.

Sedangkan menurut Abdul Majid, fungsi atau manfaat perencanaan pembelajaran dalam proses belajar mengajar, yaitu: ${ }^{12}$

a. Sebagai kompas kegiatan untuk mencapai tujuan.

b. Sebagai dasar dalam pengakomodasian tugas dan wewenang bagi tiap-tiap individu yang terlibat dalam pembelajaran

c. Sebagai panduan kerja bagi tiap individu, baik itu guru maupun siswa.

d. Sebagai barometer keefektifan suatu pekerjaan, agar dapat disadari ketepatan dan kelambatan kerjanya.

e. Sebagai bahan penyusunan data agar tercipta keseimbangan kerja.

f. Untuk mengefisienkan waktu, menghemat tenaga/energi, alat-alat dan ongkos atau pengeluaran

\section{Langkah-Langkah Penyusunan RPP}

Menurut Permendikbud No. 81 tahun 2013 ada beberapa langkah yang harus diterapkan dalam penyusunan RPP, antara lain berikut ini:

1. Mencantukan identitas. Identitas yang dimaksud ialah nama satuan pendidikan, mata pelajaran, kelas atau rombongan belajar, semester,

${ }^{12}$ Abdul Majid, Perencanaan Pembelajaran Mengembangkan Standar Kompetensi Guru, (Bandung: PT. Remaja Rosdakarya, 2005), h. 22 serta alokasi waktu yang sesuai dengan kebutuhan dalam mencapai KD dan beban belajar.

2. Menetapkan Kompetensi Dasar (KD) dan indikator pencapaian kompetensi yang dijabarkan dari silabus.

3. Menetapkan tujuan pembelajaran berdasarkan apa yang ada di KD dengan memakai kata operasional yang terkait.

4. Menampilkan materi pembelajaran dalam wujud uraian sesuai dengan indikator pencapaian kompetensi.

5. Memilih cara belajar yang sejalan dengan kondisi dan keadaan siswa serta ciri dari setiap kompetensi yang ingin dicapai.

6. Menguraikan langkah-langkah kegiatan pembelajaran yakni kegiatan pembuka, inti, dan tentunya kegiatan penutup.

7. Mencantumkan media dan sumber belajar.

8. Penetapan sumber belajar berorientasi pada rumusan yang terdapat di silabus yang mana sumber tersebut harus merangkap sumber rujukan, alam sekitar, alat dan bahan serta media cetak dan elektronik.

9. Menetapkan penilaian yang mencakup penilaian terhadap proses maupun hasil belajar. Penilaian tersebut meliputi teknik, bentuk, instrumen penilaian, kunci jawaban, serta pedoman penskoran. ${ }^{13}$

\section{Faktor yang Mempengaruhi Kemampuan Guru}

Guru ialah tenaga yang profesional dalam mengembang amanah sebagai instruktur, mendidik, melatih, menuntun, mengarahkan, memelihara, mengasuh, menggembleng, memberi penilaian, dan mengevaluasi peserta didik. Didalam PP No. 19 Tahun 2005 tentang Standar Nasional Pendidikan mengutarakan bahwa ada 8 standar yang harus di-

\footnotetext{
${ }^{13}$ Antonius, Buku Pedoman Guru, (Bandung: Yrama Widiya, 2016), h. 54
} 
penuhi setiap satuan pendidikan dalam menjalankan tugasnya. Salah satu standar tersebut yakni standar pendidik dan tenaga kependidikan yang menerangkan bahwa guru yang kompeten mempunyai kapabilitas akademik, kepiawaian sebagai agen pembelajaran, sehat jiwa dan fisik, serta mempunyai kapasitas untuk merealisasikan tujuan pendidikan nasional.

Berikut ini ada beberapa faktor yang turut andil dalam mempengaruhi kemampuan guru yaitu sebagai berikut: 14

1. Etos kerja

2. Kualifikasi pendidikan

3. Pengalaman mengajar

4. Beban mengajar

5. Kesejahteraan

6. Kegiatan MGMP

7. Status kepegawaian

8. Sarana dan prasaran sekolah

Pendapat tersebut mengisyaratkan bahwa guru merupakan faktor penyebab yang dapat mempengaruhi tinggi rendahnya mutu pendidikan utamanya di Indonesia. Sehingga keberadaan guru urgen, terutama guru yang memiliki kapabilitas yang mumpuni, menguasai materi yang diajarkan, serta selalu berupaya mengembangakn dan memajukan skill dibidangnya.

\section{Hasil Penelitian}

Berdasarkan hasil penelitian yang dilakukan penulis terhadap analisis kemampuang guru Akidah Akhlak dalam penyusunan rencana pelaksanaan pembelajaran (RPP) kurikulum 2013 di MTs Negeri Kota Palopo yaitu:

Tabel 1. Hasil Observasi I terhadap Kemampuan Guru Akidah Akhlak dalam Penyusunan RPP Kurikulum 2013 di MTs Negeri Kota Palopo

Nama

: Herlina, S.Pd.I.

${ }^{14}$ Murip Yahya, Profesi Tenaga Kependidikan, (Bandung: Pustaka Setia, 2013), h. 23

$$
\begin{array}{ll}
\text { Hari/Tgl } & : \text { Selasa/10 Desember } 2019 \\
\text { Waktu } & : 10.00-11.22 \\
\text { Tempat } & : \text { MTs Negeri Kota Palopo } \\
\text { Kelas } & : \text { VII a }
\end{array}
$$

\begin{tabular}{|c|c|c|c|}
\hline \multirow{2}{*}{ No. } & \multirow{2}{*}{ Hal yang diamati } & \multicolumn{2}{|c|}{ Keterangan } \\
\hline & & Ya & Tidak \\
\hline 1. & $\begin{array}{l}\text { Guru menggarap } \mathrm{RPP} \\
\text { kurikulum } 2013\end{array}$ & & \\
\hline 2. & $\begin{array}{l}\text { Guru menuliskan } \\
\text { personalitas, nama satuan } \\
\text { pendidikan, mata } \\
\text { pelajaran/tema subtema, } \\
\text { kelas, semester, alokasi } \\
\text { waktu }\end{array}$ & & \\
\hline 3. & $\begin{array}{l}\text { Menguraikan Kompetensi } \\
\text { Dasar, dan indikator } \\
\text { pencapaian kompetensi } \\
\text { yang diambil dari silabus }\end{array}$ & & \\
\hline 4. & $\begin{array}{l}\text { Kerincian dan } \begin{array}{l}\text { kejelasan } \\
\text { indikator pencapaian } \\
\text { kompetensi }\end{array} \\
\end{array}$ & & \\
\hline 5. & $\begin{array}{l}\text { Ketepatan } \\
\text { tujuan perumusan } \\
\text { dengan kompetensi inti }\end{array}$ & & \\
\hline 6. & $\begin{array}{l}\text { Ketetapan materi } \\
\text { pembelajaran }\end{array}$ & & \\
\hline 7. & $\begin{array}{ll}\text { Keterkaitan } & \text { metode } \\
\text { dengan tujuan, } & \text { materi, } \\
\text { dan karakteristik } & \text { peserta } \\
\text { didik } & \\
\end{array}$ & & \\
\hline 8. & Kekompletan media & & \\
\hline 9. & $\begin{array}{ll}\text { Kesinkronan } & \text { media } \\
\text { dengan } & \text { materi } \\
\text { pembelajaran } & \\
\end{array}$ & & \\
\hline 10. & $\begin{array}{l}\text { Kesesuaian sumber belajar } \\
\text { dengan materi } \\
\text { pembelajaran }\end{array}$ & & \\
\hline 11. & $\begin{array}{lr}\begin{array}{l}\text { Kejelasan } \\
\text { pembelajaran }\end{array} & \begin{array}{r}\text { skenario } \\
\text { (langkah- } \\
\text { langkah } \\
\text { pembelajaran: }\end{array} \\
\text { pendahuluan, } \\
\text { penutup) }\end{array}$ & & \\
\hline 12. & $\begin{array}{lr}\text { Keserasian } & \text { teknik } \\
\text { penilaian } & \text { dengan } \\
\text { kompetensi } & \text { yang akan } \\
\text { dicapai } & \end{array}$ & & \\
\hline 13. & $\begin{array}{l}\text { Kekompletan perangkat } \\
\text { penilaian (soal, kunci, } \\
\text { rubrik penilaian) }\end{array}$ & & \\
\hline 14. & $\begin{array}{l}\text { Ketelitian antara } \\
\text { komponenen yang satu } \\
\text { dan lainnya. }\end{array}$ & & \\
\hline & Jumlah $\frac{1}{1} \times 1 \%$ & 12 & 2 \\
\hline & Skor $86 \%$ & $86 \%$ & $14 \%$ \\
\hline
\end{tabular}

Kemampuan guru yang dicapai: $86 \%$ 
Keterangan :

Skor $86-100 \%$ : Baik sekali

Skor $71-85 \%$ : Baik

Skor 55-70\% : Cukup

Berdasarkan hasil observasi I diperoleh data bahwa kemampuan guru Akidah Akhlak dalam penyusunan RPP kurikulum 2013 di MTs Negeri Kota Palopo dari 14 item indikator, maka sebanyak 12 item (86\%) yang sudah dilaksanakan dan 2 item (14\%) yang belum dilaksanakan. Kedua item yang tidak dilaksanakan yaitu pada point ke-8 dan point ke-13. Point 8 menunjukkan kekompletan media, sementara point ke-13 menunjukkan kekompletan perangkat penilaian (soal, kunci, rubrik penilaian).

Skor penilaian tentang kemupuan guru Akidah Akhlak dalam penyusunan RPP kurikulum 2013 pada kegiatan observasi I dapat disimpulkan sudah dilakukan dengan baik sekali. Hal ini menunjukkan sebanyak 12 item (86\%) yang terjawab dilaksanakan. Sehingga kemampuan guru Akidah Akhlak dalam penyusunan RPP kurikulum 2013 pada kegiatan observasi I dinilai kemampuan guru yang telah dicapai.

Tabel 2. Hasil Observasi II terhadap Kemampuan Guru Akidah Akhlak dalam Penyusunan RPP Kurikulum 2013 di MTs Negeri Kota Palopo

$\begin{array}{ll}\text { Nama } & \text { : Nasirah, S.Pd.I., M.Pd.I. } \\ \text { Hari/Tgl } & : \text { Selasa/10 Desember } 2019 \\ \text { Waktu } & : 14.00-15.58 \\ \text { Tempat } & : \text { MTs Negeri Kota Palopo } \\ \text { Kelas } & : \text { VIII e }\end{array}$

\begin{tabular}{|c|c|c|c|}
\hline \multirow{2}{*}{ No. } & \multirow{2}{*}{ Hal yang diamati } & \multicolumn{2}{|c|}{ Keterangan } \\
\hline & & Ya & Tidak \\
\hline 1. & $\begin{array}{l}\text { Guru menggarap RPP } \\
\text { kurikulum } 2013\end{array}$ & & \\
\hline 2. & $\begin{array}{lr}\text { Guru menuliskan } \\
\text { personalitas, nama } \\
\text { satuan pendidikan, } \\
\text { mata pelajaran/tema } \\
\text { subtema, relas, } \\
\text { semester, alokasi } \\
\text { waktu }\end{array}$ & & \\
\hline 3. & $\begin{array}{lr}\text { Menguraikan } \\
\text { Kompetensi } \\
\text { dan Dasar, }\end{array}$ & & \\
\hline
\end{tabular}

\begin{tabular}{|c|c|c|c|}
\hline \multirow{2}{*}{ No. } & \multirow{2}{*}{ Hal yang diamati } & \multicolumn{2}{|c|}{ Keterangan } \\
\hline & & Ya & Tidak \\
\hline & $\begin{array}{l}\text { pencapaian } \\
\text { kompetensi yang } \\
\text { diambil dari silabus }\end{array}$ & & \\
\hline 4. & $\begin{array}{lr}\text { Kerincian } & \text { dan } \\
\text { kejelasan } & \text { indikator } \\
\text { pencapaian } & \\
\text { kompetensi } & \end{array}$ & & \\
\hline 5. & \begin{tabular}{lr}
\multicolumn{2}{l}{ Ketepatan perumusan } \\
tujuan pembelajaran \\
dengan kompetensi \\
inti
\end{tabular} & & \\
\hline 6. & $\begin{array}{ll}\text { Ketetapan } & \text { materi } \\
\text { pembelajaran } & \end{array}$ & & \\
\hline 7. & $\begin{array}{l}\text { Keterkaitan metode } \\
\text { dengan tujuan, materi, } \\
\text { dan karakteristik } \\
\text { peserta didik }\end{array}$ & & \\
\hline 8. & Kekompletan media & & \\
\hline 9. & $\begin{array}{ll}\text { Kesinkronan } & \text { media } \\
\text { dengan } & \text { materi } \\
\text { pembelajaran } & \end{array}$ & & \\
\hline 10. & $\begin{array}{l}\text { Kesesuaian sumber } \\
\text { belajar dengan materi } \\
\text { pembelajaran }\end{array}$ & & \\
\hline 11. & $\begin{array}{l}\text { Kejelasan skenario } \\
\text { pembelajaran } \\
\text { (langkah-langkah } \\
\text { kegiatan } \\
\text { pembelajaran: } \\
\text { pendahuluan, inti, } \\
\text { penutup) }\end{array}$ & & \\
\hline 12. & $\begin{array}{l}\text { Keserasian teknik } \\
\text { penilaian dengan } \\
\text { kompetensi yang akan } \\
\text { dicapai }\end{array}$ & & \\
\hline 13. & $\begin{array}{l}\text { Kekompletan } \\
\text { perangkat penilaian } \\
\text { (soal, kunci, rubrik } \\
\text { penilaian) }\end{array}$ & & \\
\hline 14. & $\begin{array}{l}\text { Ketelitian antara } \\
\text { komponenen yang } \\
\text { satu dan lainnya. }\end{array}$ & & \\
\hline & Jumlah $\frac{1}{1} \times 1 \%$ & 11 & 3 \\
\hline & Skor 78\% & $78 \%$ & $22 \%$ \\
\hline
\end{tabular}

Kemampuan guru yang dicapai: $78 \%$

Keterangan :

Skor $86-100 \%$ : Baik sekali

Skor $71-85 \%$ : Baik

Skor $55-70 \%$ : Cukup

Berdasarkan hasil observasi II diperoleh data bahwa kemampuan guru Akidah Akhlak dalam 
penyusunan RPP kurikulum 2013 di MTs Negeri Kota Palopo dari 14 item indikator, maka sebanyak 11 item (78\%) yang sudah dilaksanakan dan 3 item (22\%) yang belum dilaksanakan. Ketiga item yang tidak dilaksanakan yaitu pada point ke-4, point ke8 dan point ke-13. Point ke-4 Kerincian dan kejelasan indikator pencapaian kompetensi, point 8 menunjukkan kekompletan media, dan point ke-13 menunjukkan kekompletan perangkat penilaian (soal, kunci, rubrik penilaian).

Skor penilaian tentang kemupuan guru Akidah Akhlak dalam penyusunan RPP kurikulum 2013 pada kegiatan observasi II dapat disimpulkan sudah dilakukan dengan baik. Hal ini menunjukkan sebanyak 11 item (78\%) yang terjawab dilaksanakan. Sehingga kemampuan guru Akidah Akhlak dalam penyusunan RPP kurikulum 2013 pada kegiatan observasi II dinilai kemampuan guru yang telah dicapai.

Tabel 3. Hasil Observasi III terhadap Kemampuan Guru Akidah Akhlak dalam Penyusunan RPP Kurikulum 2013 di MTs Negeri Kota Palopo Nama : Sitti. Hajrah, S.Ag.

Hari/Tgl

: Senin/09 Desember 2019

Waktu

$: 10.00-11.22$

Tempat

: MTs Negeri Kota Palopo

Kelas

: IX b

\begin{tabular}{|c|c|c|c|}
\hline \multirow{2}{*}{ No. } & \multirow{2}{*}{ Hal yang diamati } & \multicolumn{2}{|c|}{ Keterangan } \\
\hline & & Ya & Tidak \\
\hline 1. & $\begin{array}{l}\text { Guru menggarap } \\
\text { kurikulum } 2013\end{array}$ & & \\
\hline 2. & $\begin{array}{lr}\text { Guru } & \text { menuliskan } \\
\text { personalitas, nama satuan } \\
\text { pendidikan, } & \text { mata } \\
\text { pelajaran/tema } & \text { subtema, } \\
\text { kelas, semester, alokasi } \\
\text { waktu }\end{array}$ & & \\
\hline 3. & $\begin{array}{lr}\text { Menguraikan } & \text { Kompetensi } \\
\text { Dasar, dan } & \text { indikator } \\
\text { pencapaian } & \text { kompetensi } \\
\text { yang diambil dari silabus }\end{array}$ & & \\
\hline 4. & $\begin{array}{l}\begin{array}{l}\text { Kerincian dan } \\
\text { indikator kejelasan } \\
\text { kompetensi }\end{array} \\
\text { pencapaian }\end{array}$ & & \\
\hline 5. & $\begin{array}{l}\text { Ketepatan perumusan } \\
\text { tujuan pembelajaran dengan }\end{array}$ & & \\
\hline
\end{tabular}

\begin{tabular}{|c|c|c|c|}
\hline \multirow{2}{*}{ No. } & \multirow{2}{*}{ Hal yang diamati } & \multicolumn{2}{|c|}{ Keterangan } \\
\hline & & Ya & Tidak \\
\hline & kompetensi inti & & \\
\hline 6. & $\begin{array}{ll}\text { Ketetapan } & \text { materi } \\
\text { pembelajaran } & \end{array}$ & & \\
\hline 7. & $\begin{array}{l}\text { Keterkaitan metode dengan } \\
\text { tujuan, materi, dan } \\
\text { karakteristik peserta didik }\end{array}$ & & \\
\hline 8. & Kekompletan media & & \\
\hline 9. & $\begin{array}{l}\text { Kesinkronan media dengan } \\
\text { materi pembelajaran }\end{array}$ & & \\
\hline 10. & $\begin{array}{l}\text { Kesesuaian sumber belajar } \\
\text { dengan materi pembelajaran }\end{array}$ & & \\
\hline 11. & $\begin{array}{lr}\text { Kejelasan } & \text { skenario } \\
\text { pembelajaran } & \text { (langkah- } \\
\text { langkah } & \text { kegiatan } \\
\text { pembelajaran: pendahuluan, } \\
\text { inti, penutup) }\end{array}$ & & \\
\hline 12. & $\begin{array}{l}\text { Keserasian teknik penilaian } \\
\text { dengan kompetensi yang } \\
\text { akan dicapai }\end{array}$ & & \\
\hline 13. & $\begin{array}{l}\text { Kekompletan perangkat } \\
\text { penilaian (soal, kunci, rubrik } \\
\text { penilaian) }\end{array}$ & & \\
\hline 14. & $\begin{array}{l}\text { Ketelitian antara } \\
\text { komponenen yang satu dan } \\
\text { lainnya. }\end{array}$ & & \\
\hline & Jumlah $\frac{1}{1} \times 1 \%$ & 12 & 2 \\
\hline & Skor $86 \%$ & $86 \%$ & $14 \%$ \\
\hline
\end{tabular}

Kemampuan guru yang dicapai: $86 \%$

Keterangan :

Skor $86-100 \%$ : Baik sekali

Skor $71-85 \%$ : Baik

Skor $55-70 \%$ : Cukup

Berdasarkan hasil observasi III diperoleh data bahwa kemampuan guru Akidah Akhlak dalam penyusunan RPP kurikulum 2013 di MTs Negeri Kota Palopo dari 14 item indikator, maka sebanyak 12 item (86\%) yang sudah dilaksanakan dan 2 item (14\%) yang belum dilaksanakan. Kedua item yang tidak dilaksanakan yaitu pada point ke-4 dan point ke-13. Point ke-4 Kerincian dan kejelasan indikator pencapaian kompetensi, dan point ke-13 menunjukkan kekompletan perangkat penilaian (soal, kunci, rubrik penilaian).

Skor penilaian tentang kemampuan guru Akidah Akhlak dalam penyusunan RPP kurikulum 2013 pada kegiatan observasi III dapat disimpulkan 
sudah dilakukan dengan baik. Hal ini menunjukkan sebanyak 12 item (86\%) yang terjawab dilaksanakan. Sehingga kemampuan guru Akidah Akhlak dalam penyusunan RPP kurikulum 2013 pada kegiatan observasi III dinilai kemampuan guru yang telah dicapai.

\section{Analisis Faktor yang Mempengaruhi Kemam- puan Guru dalam Penyusunan RPP Kuriku- lum 2013}

Salah satu kemampuan yang perlu dimiliki seorang guru dalam proses pembelajaran adalah kemampuan menyusun RPP. Kehadiran RRP menjadi acuan dalam melaksanakan kegiatan proses pembelajaran. Perencananan bertujuan, agar penyampaian materi pelajaran sistematis, interaktif, inspiratif, menyenangkan, menantang, memotivasi peserta didik untuk berpartisipasi aktif, dan tujuan pembelajaran dapat tercapai. Sehingga penyusunan RRP sebelum kegiatan pembelajaran urgen bagi masingmasing guru.

Berdasarkan hasil penelitian yang penulis temukan di lapangan mengenai kemampuan guru Akidah Akhlak dalam penyusunan RPP kurikulum 2013 di MTs Negeri Kota Palopo, dipengaruhi oleh dua faktor yang mempengaruhinya yaitu:

\section{Faktor Internal}

Faktor internal yaitu berkaitan kondisi internal yang dimiliki oleh guru yang bersangkutan. Faktor internal guru yang dimakasud adalah berkaitan dengan pemahaman, kemampuang, dan pengetahuan guru tentang perangkat pembelajaran dan penyusunan RPP. Seperti yang disampaikan oleh ibu Nasirah bahwa salah satu faktor yang mempengaruhi kemampuan guru dalam menyusun RPP kurikulum 2013 adalah pemahaman guru tentang perangkat pembelajaran dan penyusunan RPP.

\section{Faktor Eksternal}

Faktor eksternal berkaitan dengan kondisi luar guru. Eksternal guru yang dimaksud berkaitan den- gan ketersediaan waktu, sehingga guru dapat menyusun perangkat pembelajaran secara optimal. Ketersediaan sarana atau media di sekolah. Kondisi dan karakter siswa yang perlu dipahami dalam proses penyusunan RPP.

Kurikulum 2013 mensyaratkan setiap guru memiliki perangkat pembelajaran yang komplet dan tertata karena menjadi acuan proses belajar mengajar di kelas. RPP yang telah dibuat sedemikian rupa dapat berubah karena disesuaikan kondisi dan karakteristik siswa, memungkinkan diubah model pembelajarannya sesuai dengan tingkat kemampuan siswa agar berjalan proses pembelajaran bejalan sesuai perencanaan. Sebagaimana diutarakan ibu Sitti Hajrah bahwa format RPP yang selalu berubah-ubah sangatlah berpengaruh pada guru hingga mengakibatkan guru tidak dapat menyusun perangkat pembelajaran dengan optimal.

RPP merupakan pedoman guru dalam menjalankan kegiatan pembelajaran di kelas. Guru diharap mampu berinovasi dan kreatif dalam mengembangkan setiap RPP yang ia buat, melakukan terobosan-terobosan baru yang sesuai dengan karakter siswa. Oleh karena itu setiap guru pada satuan pendidikan meningkatkan kompetensi atau kemampuan dalam menyusun RPP, mencari informasi dan berpartisioasi dalam kegiatan pelatihan berkenaan dengan perangkat pembelajaran dan terkhusus pada penyusunan RPP.

Analisa data pada penelitian ini didasarkan pada data hasil observasi yang telah penulis sajikan dalam tabel penyajian data sebelumyan. Hasil observasi dengan informan guru Akidah Akhlak di MTs Negeri Kota Palopo yang telah dijabarkan pada penyajian data hasil penelitian diatas, maka penyusunan RPP K13 yang baik dan benar hendaknya meliputi beberapa hal sebagai berikut:

1. Guru menggarap RPP kurikulum 2013 
2. Guru menuliskan personalitas, nama satuan pendidikan, mata pelajaran/tema subtema, kelas, semester, alokasi waktu

3. Menguraikan Kompetensi Dasar, dan indikator pencapaian kompetensi yang diambil dari silabus

4. Kerincian dan kejelasan indikator pencapaian kompetensi

5. Ketepatan perumusan tujuan pembelajaran dengan kompetensi inti

6. Ketetapan materi pembelajaran

7. Keterkaitan metode dengan tujuan, materi, dan karakteristik peserta didik

8. Kekompletan media

9. Kesinkronan media dengan materi pembelajaran

10. Kesesuaian sumber belajar dengan materi pembelajaran

11. Kejelasan skenario pembelajaran (langkahlangkah kegiatan pembelajaran: pendahuluan, inti, penutup)

12. Keserasian teknik penilaian dengan kompetensi yang akan dicapai

13. Kekompletan perangkat penilaian (soal, kunci, rubrik penilaian)

14. Ketelitian antara komponenen yang satu dan lainnya.

Berdasarkan 14 item indikator yang diuraikan sebelumnya, serta menjadi angket dalam kegiatan obeservasi tentang kemampuan guru Akidah Akhlak dalam penyusunan RPP kurikulum 2013 di MTs Negeri Kota Palopo, maka disimpulkan bahwa pada kegiatan obeservasi I hasil skor penilaian tentang kemupuan guru Akidah Akhlak dalam penyusunan RPP kurikulum 2013 dapat disimpulkan sudah dilakukan dengan baik sekali. Hal ini menunjukkan sebanyak 12 item 86\% (baik sekali) yang terjawab dilaksanakan. Sehingga kemampuan guru Akidah Akhlak dalam penyusunan RPP kuri- kulum 2013 pada kegiatan observasi I dinilai kemampuan guru yang telah dicapai.

Kegiatan obeservasi II hasil skor penilaian tentang kemupuan guru Akidah Akhlak dalam penyusunan RPP kurikulum 2013 pada kegiatan observasi II dapat disimpulkan sudah dilakukan dengan baik. Hal ini menunjukkan sebanyak 11 item $78 \%$ (baik) yang terjawab dilaksanakan. Sehingga kemampuan guru Akidah Akhlak dalam penyusunan RPP kurikulum 2013 pada kegiatan observasi II dinilai kemampuan guru yang telah dicapai.

Kegiatan obeservasi III hasil skor penilaian tentang kemampuan guru Akidah Akhlak dalam penyusunan RPP kurikulum 2013 pada kegiatan observasi III dapat disimpulkan sudah dilakukan dengan baik. Hal ini menunjukkan sebanyak 12 item $86 \%$ (baik) yang terjawab dilaksanakan. Sehingga kemampuan guru Akidah Akhlak dalam penyusunan RPP kurikulum 2013 pada kegiatan observasi III dinilai kemampuan guru yang telah dicapai.

Hasil kegiatan observasi yang dilakukan pada tahap I, II, dan III menjukkan bahwa kemampuan guru Akidah Akhlak di MTs Negeri Kota Palopo dalam meyusun RPP kurikulum 2013 yaitu sudah "baik" dengan rata-rata skor $83.33 \%$ (sangat baik). Hal ini menunjukkan angka yang sangat baik terhadap kemampuan guru Akidah Akhlak dalam penyusunan RPP kurikulum 2013. Sehingga perencanaan pembelajaran memiliki fungsi atau manfaat dalam proses pembelajaran, sebagaimana Majid menguraikan yaitu: 1) sebagai kompas kegiatan untuk mencapai tujuan.2) Sebagai dasar dalam pengakomodasian tugas dan wewenang bagi tiaptiap individu yang terlibat dalam pembelajaran, 3) sebagai panduan kerja bagi tiap individu, baik itu guru maupun siswa, 4) sebagai barometer keefektifan suatu pekerjaan, agar dapat disadari ketepatan dan kelambatan kerjanya, dan sebagai bahan penyusunan data agar tercipta keseimbangan kerja, dan 5) untuk mengefisienkan waktu, menghemat 
tenaga/energi, alat-alat dan ongkos atau pengeluaran.

\section{Kesimpulan}

Bedasarkan penelitian yang penulis lakukan tentang analisis kemampuan penyusunan RPP kurikulum 2013 oleh guru Akidah Akhlak di MTs Negeri Kota Palopo, setelah mengumpulkan, mengolah dan menganalisis data yang telah dijabarkan pada pembahasan sebelumnya, dapat disimpulkan bahwa guru Akidah Akhlak dalam penyusunan RPP kurikulum 2013 di MTs Negeri Kota Palopo telah menunjukkan hasil yang baik dengan rata-rata skor $83.33 \%$ (sangat baik). Sebelum proses pembelajaran guru telah membuat dan menyusun RPP secara tepat sesuai dengan standar yang telah ditentukan oleh pemerintah dan sesuai dengan keperluan siswa, menggunakan cara belajar yang sesuai dengan materi untuk mencapai tujuan pembelajaran.

Kemampuan guru Akidah Akhlak dalam penyusunan RPP kurikulum 2013 di MTs Negeri Kota Palopo, dipengaruhi oleh dua faktor yang mempengaruhinya yaitu faktor internal dan eksternal. Faktor Internal yaitu berkaitan dengan pemahaman, kemampuang, dan pengetahuan guru tentang perangkat pembelajaran dan penyusunan RPP. Faktor eksternal berkaitan dengan ketersediaan waktu, sehingga guru dapat menyusun perangkat pembelajaran secara optimal. Ketersediaan sarana atau media di sekolah. Kondisi dan karakter siswa yang perlu dipahami dalam proses penyusunan RPP.

\section{DAFTAR PUSTAKA}

Abdul Majid, Perencanaan Pembelajaran Mengembangkan Standar Kompetensi Guru, (Bandung: PT. Remaja Rosdakarya, 2005)

Antonius, Buku Pedoman Guru, (Bandung: Yrama Widiya, 2016)
Badan Standar Nasional Pendidikan, Peraturan Menteri Pendidikan RI No. 41 Tahun 2007 Tentang Standar Proses Untuk Satuan Pendidikan Dasar dan Menengah, (Jakarta, Bumi Aksara, 2007)

Victor Uji Kurnia, "Definisi Guru Profesional", Blog Victor Uji Kurnia. http://informasipendidikan.com/2013/07/definisi guru -profesional.html(22 Desember 2019)

Erni Vidiarti, dkk. Analisis Kemampuan Guru Pendidikan Agama Islam dalam Penyusunan Rencana Pelaksanaan Pembelajaran (RPP) Kurikulum 2013, Jurna Pendidikan Agama IslamVol. 5, No. 2, 2019. h. 102-112. http://ejournal.uinmalang.ac.id/index.php/jpai/

Hamzah B. Uno, Orientasi Baru dalam Psikologi Pembelajaran, (Jakarta: Bumi Aksara, 2006)

Lailatul Bariyah, Analisis Kesesuaian RPP dan Pelaksanaan Pembelajaran Guru SMPN di Kabupaten Mojokerto pada Sub Materi Fotosintesis dengan Kurikulum 2013. Jurnal BioEdu (Berkah Ilmiah Pendidikan Biologi, Vol. 3, Vo. 3, 2014. h. 453-460. https://jurnalmahasiswa.unesa.ac.id/index.p hp/bioedu/article/download/ 9558/9439

Mulyasa, Kurikulum Tingkat Satuan Pendidikan, (Bandung: PT. Remaja Rosdakarya, 2007)

Murip Yahya, Profesi Tenaga Kependidikan, (Bandung:Pustaka Setia, 2013)

Muslich, Kurikulum Tingkat Satuan Pendidikan: Dasar Pemahaman dan Pengembangan, (Jakarta: Bumi Aksara, 2008) 
Suharsimi Ari Kunto, Prosedur Penelitian:

SuatuPendekatan Praktek, (Jakarta: Rineka

Cipta, 2010)

Yuliharti, dkk, Modul Pengembangan Rencana

Pelaksanaan Pembelajaran, (Pekanbaru:

Zanafa Publishing, 2014) 
ANALISIS KEMAMPUAN GURU AKIDAH AKHLAK DALAM PENYUSUNAN RENCANA PELAKSANAAN PEMBELAJARAN (RPP) KURIKULUM 2013 DI MTS NEGERI KOTA PALOPO 